International Journal of Current Microbiology and Applied Sciences

ISSN: 2319-7706 Volume 10 Number 08 (2021)

Journal homepage: http://www.ijcmas.com

\title{
Study of Integrated Nutrient Management on Growth, Yield and Quality of Radish (Raphanus sativus L.)
}

\author{
Akshay Sawant ${ }^{1}$, Ch. Raja Goud ${ }^{2}$, T. Suresh Kumar ${ }^{3}$, D. Anitha Kumari ${ }^{4}$ and P. Satish ${ }^{5}$ \\ ${ }^{1}$ Department of Vegetable Science, College of Horticulture (SKLTSHU), \\ Rajendranagar, Hyderabad-500030, India \\ ${ }^{2}$ Department of Horticulture, Rajendranagar, Hyderabad, India \\ ${ }^{3}$ Horticulture Research Station, Konda Mallepally, Nalgonda, India \\ ${ }^{4}$ Vegetable Research Station, Rajendranagar, Hyderabad, India \\ ${ }^{5}$ College Farm, PJTSAU, Rajendranagar, Hyderabad, India \\ *Corresponding author
}

\section{A B S T R A C T}

Keywords

Radish, FYM, NPK,

Vermicompost,

Neemcake,

microbial

consortium

Article Info

Accepted:

15 July 2021

Available Online:

10 August 2021
The field experiment was conducted during the rabi season of the year 2019-20 at Sri Konda Laxman Telangana State Horticultural University, College of Horticulture, Rajendranagar, Hyderabad, Telangana to evaluate "study of integrated nutrient management on growth, yield and quality of radish (Raphanus sativus L.)' 'The experiment was laid out in Randomized Block Design with seven different levels of treatment of integrated nutrients and three cultivars replication thrice. Results revealed that yield parameters significantly affected with the application of varying levels of integrated nutrients as well as cultivars. Among the treatment plant height per plant $(37.4 \mathrm{~cm})$, number of leaves per plant (21.0) higher root length per plant $(28.81 \mathrm{~cm})$, root weight of plant $(267.33 \mathrm{~g})$, root diameter $(3.38 \mathrm{~cm})$, b:c ratio (1.17)was recorded at $\mathrm{RDF}(90: 50: 90) \mathrm{kg} \mathrm{ha}^{1}+$ farm yard manures (5t/ha) + verimicompost (3t/ha) + arka microbial constrioum $(17 \mathrm{~kg} / \mathrm{ha})$ was cultivar Japanese white.

\section{Introduction}

Radish (Raphanus sativus L.) locally known as mula, mullangi, mullo, mooli and milli that belongs to the family cruciferae. It is considered to be the native of China and India.
It is one of the most ancient vegetables. Radish is grown for its tuberous root, which are eaten raw as salad or cooked as vegetable. It is relished for its pungent taste and flavour and is considered as an appetizer. The characteristic pungent flavour of radish is due 
to the volatile isothiocyanates (trans-4 methyl-thibutenyl-isothiocynate) and the colour of the pink cultivars is due to the presence of anthocyanin pigments. The tender leaves are also cooked and eaten as vegetables. Radish has refreshing and depurative properties and its preparation are useful in liver and gall bladder troubles. In homeopathy, it is used for neuralgic headaches and sleeplessness. The roots are said to be useful in urinary complaints, piles, gastrodynia, enlarged spleen, and jaundice and stomach troubles. The juice of fresh leaves is used as diuretics and laxative.

Radish is nutritious vegetables providing a good source of vitamin-B and Vitamin-C content in roots and shoots are 15$40 \mathrm{mg} / 100 \mathrm{gm}$ and $103 / 100 \mathrm{gm}$ of edible portion, respectively (Gopalan and Balasubramanium, 1966). The tracer mineral element found in radish include aluminum, titanium, barium, lithium, silicon, fluorine and iodine.

Radish being a short duration and quick growing crop. The root growth is rapid and uninterrupted. Hence, for the production of good quality roots and higher yield, optimum fertilizers especially nitrogen, phosphorous and potassium assume special significance. The growth of radish plant is checked due to lack of nitrogen and substantially by phosphorous and potassium (Lacas and De Frietas, 1960).

Soil fertility is a dynamic property, which varies with in the rent status of soil, Crops, cropping intensity, and input use. More than $50 \%$ of our cultivated soil contains organic matter below the critical level. Annual depletion of plant nutrients in the intensively cropped area ranges from 180 to $250 \mathrm{~kg} / \mathrm{ha}$. High and medium highland comprising 60\% of total cultivated land, which in most cases deficient in essential nutrients, such as nitrogen, phosphorus, potassium, and sulphur.
The low organic matter content, higher cropping intensity, improper cropping sequence, and faulty management Practices are the major causes of depletion of soil fertility. The productivity, particularly the yield per unit area of a wide range of crops in Telangana state is due to little or no addition of organic matter to the soil, Intensive cropping throughout the year, nutrient depletion, imbalanced fertilization, and poor management practices in crop production

Crop production system with high yield targets cannot be sustainable unless balanced nutrient inputs are supplied to soil against nutrient removable crops (Bhuiyan et al., 1991). Sequential cropping ensures maximization of efficient use of moisture and nutrients from soil. Integrated nutrient management for prevailing cropping systems appears to be one of the effective ways to meet the economical nutrition requirement of crop.

Radish is a cultivated variety, suitable on account of its versatile adaptability and also suitable to tropical conditions. Among the various factors influencing yield, adequate nutrition and plant spacing are the most important. Application of nitrogen, phosphorus and potash along with organic manures such as FYM, vermicomposting, and castor cake significantly increased the leaf area, number of leaves, length and diameter of root as well as root yield. (Velmurugan et al., 2005).

The growing of radish plants has been affected most severely due to lack of $\mathrm{N}$ and subsequently by $\mathrm{P}$ as well as $\mathrm{K}$. Growth and yield of radish have been found to increase significantly in response to the application. According to the phosphorus deficient radish plants were shorter in height, leaves were distorted in shape and pink tinge appeared along the margins and veins. In potassium- 
deficient plants the color of leaves changed from green to pale yellow and brown scorches appeared on the leaves at later stages. Violet streaks appeared on roots which ultimately spread all over. While overall affected yield and quantity of radish the TSS content of radish significantly increased with increasing level of nitrogen (Desuki et al., 2005).

Thus, it is essential to find out adequate nutrient requirements of nitrogen, phosphorus and potash along with organic manure in radish crop.

\section{Materials and Methods}

The present experiment was conducted to find out the effect of integrated nutrient management on growth, yield and quantity in different cultivars of radish at PG Students Research Farm, College of Horticulture, Rajendranagar, Hyderabad comes under subtropical zone and is situated at a latitude of $30^{0} 17^{\prime} \mathrm{N}$, longitude of $91^{\circ} 51^{\prime} \mathrm{E}$ and altitude of 700-800 $\mathrm{m}$ above mean sea level. The experiment was laid out in Randomized Block Design replicated thrice.

\section{Treatment details}

$\mathrm{T}_{1}: \mathrm{RDF}(90: 50: 90) \mathrm{NPK} / \mathrm{ha}$

$\mathrm{T}_{2}: \mathrm{T}_{1}+$ organic manures in the form of FYM $(5 \mathrm{t} / \mathrm{ha})$

$\mathrm{T}_{3}: \mathrm{T}_{1}+$ organic manures in the form of vermicompost (3t/ha)

$\mathrm{T}_{4}: \mathrm{T}_{1}+$ organic manures in the form of neemcake $(17 \mathrm{~kg} / \mathrm{ha})$

$\mathrm{T}_{5}: \mathrm{T}_{1}+\mathrm{FYM}(5 \mathrm{t} / \mathrm{ha})+$ IIHR microbial consortium $(300 \mathrm{~g})$

$\mathrm{T}_{6}: \mathrm{T}_{1}+$ verimicompost $(3 \mathrm{t} / \mathrm{ha})+\mathrm{IIHR}$ microbial consortium $(300 \mathrm{~g})$
$\mathrm{T}_{7}: \mathrm{T}_{1}+$ neemcake $(17 \mathrm{~kg})+$ IIHR microbial consortium $(300 \mathrm{~g})$.

\section{Cultural practices}

FYM, Vermicompost, neemcake microbial consortium were incorporated in to the respective experimental plots uniformly, before sowing as basal application. N, P and K @ 90: 50: $90 \mathrm{~kg} \mathrm{ha}^{-1}$ were applied in the form of urea, single super phosphate and muriate of potash respectively. Urea was applied in two splits, the first dose as basal application and another dose at 15 days after sowing. The entire dose of single super phosphate and muriate of potash were applied at the time of sowing as basal dose. Biofertilizers were inoculated with seeds prior to sowing as a seed treatment method.

The seeds were sown in ridge and furrow system at a depth of $1.5 \mathrm{~cm}$. Thinning and gap filling was done at 20 days after sowing to maintain optimum plant population and retained only one seedling per hill. The uniform stand of plants was maintained at a spacing of $30 \mathrm{~cm}$ between the rows and $15 \mathrm{~cm}$ between the plants in a row. The data were recorded on five plants per treatment in each replication on yield and economics.

\section{Observation to be recorded}

\section{Plant of height (cm)}

The length of shoots were measured from the juncture of root and the tip of the longest leaf individually in centimetre and average length was calculated and expressed as (cm).

\section{Root diameter (cm)}

The diameter of root of five tagged plants was measured with the help of vernier calipers and average diameter was calculated and expressed as $(\mathrm{cm})$. 


\section{Root weight (g)}

The weight of root of five tagged plants was measured with the help of weighing machine and average weight was calculated and expressed as $(\mathrm{cm})$

\section{Length of root $(\mathrm{cm})$}

The length of roots was measured in centimetre with the help of ruler and the average length was recorded expressed as (cm).

\section{Numbers of leaves per plant}

The shoots used for measuring the length were used for counting the number of leaves and the average number of leaves per plant was calculated.

\section{Results and Discussion}

\section{Plant height (cm)}

Regarding plant height, highest plant height $(37.40 \mathrm{~cm})$ recorded in $\mathrm{T}_{6}\left(\mathrm{~T}_{1}+\right.$ verimicompost $3 \mathrm{t} / \mathrm{ha}+$ IIHR microbial consortium (300g) followed by the treatment $\mathrm{T}_{7}, \mathrm{~T}_{5}, \mathrm{~T}_{3}$ and $\mathrm{T}_{2}$ which were at par with each other while minimum plant height $(27.33 \mathrm{~cm})$ was recorded $\mathrm{T}_{1}$.

The increased plant height may be due to the increased dosage and beneficiary effect of integrated nutrient management this might be due to influence of nutrient, the chief constituent of protein which is essential for the formation of protoplasm leading to meristamatic activity, cell division and development of root.

These findings are in agreement with the findings of Sunanda and Reddy (2007), Gethe et al., (2006) and Mohammad et al., (2005) in carrot and onion respectively.

\section{Number of leaves per plant}

Data regarding number of leaves per plot revealed that significantly maximum number of leaves per plot was produced with the in treatment $\mathrm{T}_{6}(21.0 \mathrm{~cm})$ followed by $\mathrm{T}_{5}, \mathrm{~T}_{7}, \mathrm{~T}_{2}$, $\mathrm{T}_{3}$ and $\mathrm{T}_{4}$ and less of number of leaves per plant was reported in $T_{1}(16.40)$.

The maximum number of leaves per plant may be due to the increased dosage and beneficiary effect of integrated nutrient management.

This might be due to influence of nutrient, the chief constituent of protein which is essential for the formation of protoplasm leading to meristamatic activity, cell division and development of root.

These findings are in agreement with the findings of Sunanda and Reddy (2007), Gethe et al., (2006) and Mohammad et al., (2005) in carrot and onion respectively.

\section{Root length (cm)}

Data regarding number of leaves per plot revealed that significantly maximum root length was recorded in treatment $\mathrm{T}_{6}(28.81 \mathrm{~cm})$ followed by the treatment $\mathrm{T}_{5}, \mathrm{~T}_{7}, \mathrm{~T}_{2}, \mathrm{~T}_{3}$ and $\mathrm{T}_{4}$ which are intermediates and least root length was observed in $\mathrm{T}_{1}(24.73 \mathrm{~cm})$ under study.

Maximum root length might be due to the nutrients (N.P.K.) are starting material for biological synthesis and it also play important role in plant metabolism and being an essential constituent of diverse type metabolically active compounds like purines, pyrimidine's, enzymes, co-enzymes and alkaloids.

Thus increased availability of photosynthesis. Which consequently led to desirable C: N ratio as carbohydrate supply might be helping in larger storage in the root as well as shoot. 
Table.1 Effect of integrated nutrient management on growth parameter of Radish.

\begin{tabular}{|c|c|c|c|c|c|}
\hline Treatment & $\begin{array}{c}\text { Plant } \\
\text { height }(\mathbf{c m})\end{array}$ & $\begin{array}{l}\text { Number } \\
\text { of leaves }\end{array}$ & $\begin{array}{c}\text { Root } \\
\operatorname{length}(\mathrm{cm})\end{array}$ & $\begin{array}{c}\text { Root } \\
\text { weight }(g)\end{array}$ & $\begin{array}{c}\text { Root } \\
\text { diameter }\end{array}$ \\
\hline RDF (90:50:90) NPK/ha & $27.33^{c}$ & $16.40^{c}$ & $24.73^{\mathrm{d}}$ & $165.00^{\mathrm{g}}$ & $2.85^{\mathrm{e}}$ \\
\hline $\begin{array}{l}T_{1}+\text { Organic manures in the } \\
\text { form of FYM }(5 \mathrm{t} / \mathrm{ha})\end{array}$ & $34.47^{\mathrm{a}}$ & $18.47^{\mathrm{b}}$ & $26.13^{\text {bd }}$ & $207.67^{\mathrm{e}}$ & $3.13^{c}$ \\
\hline $\begin{array}{l}T_{1}+\text { Organic manures in the } \\
\text { form of vermicompost }(3 \mathrm{t} / \mathrm{ha})\end{array}$ & $33.80^{\mathrm{a}}$ & $18.47^{\mathrm{b}}$ & $26.67^{\mathrm{abc}}$ & $218.00^{d}$ & $3.29^{b}$ \\
\hline $\begin{array}{l}T_{1}+\text { Organic manures in the } \\
\text { form of neemcake }(17 \mathrm{~kg} / \mathrm{ha})\end{array}$ & $32.00^{b}$ & $17.73^{\mathrm{bc}}$ & $25.67^{\text {cd }}$ & $187.67^{\mathrm{f}}$ & $3.03^{\mathrm{d}}$ \\
\hline $\begin{array}{c}\mathrm{T}_{1}+\mathrm{FYM}(5 \mathrm{t} / \mathrm{ha})+\mathrm{IIHR} \\
\text { microbial consortium }(300 \mathrm{~g})\end{array}$ & $34.80^{\mathrm{a}}$ & $18.53^{\mathrm{b}}$ & $27.67^{\mathrm{a}}$ & $262.67^{b}$ & $3.28^{\mathrm{b}}$ \\
\hline $\begin{array}{c}\mathrm{T}_{1}+\text { Vermicompost }(3 \mathrm{t} / \mathrm{ha})+ \\
\text { IIHR microbial consortium } \\
(300 \mathrm{~g})\end{array}$ & $37.40^{\mathrm{a}}$ & $21.00^{\mathrm{a}}$ & $28.81^{\mathrm{a}}$ & $267.33^{\mathrm{a}}$ & $3.38^{\mathrm{a}}$ \\
\hline $\begin{array}{c}T_{1}+\text { Neemcake }(17 \mathrm{~kg})+\mathrm{IIHR} \\
\text { microbial consortium }(300 \mathrm{~g})\end{array}$ & $34.80^{\mathrm{a}}$ & $18.47^{\mathrm{b}}$ & $27.37^{\mathrm{ab}}$ & $247.33^{c}$ & $3.27^{\mathrm{b}}$ \\
\hline CD@5\% & 4.46 & 1.50 & 1.5 & 0.68 & 0.05 \\
\hline SEm \pm & 1.45 & 0.49 & 0.49 & 2.26 & 0.15 \\
\hline
\end{tabular}

Fig.1 Effect of integrated nutrient management on plant height $(\mathrm{cm})$ of radish.

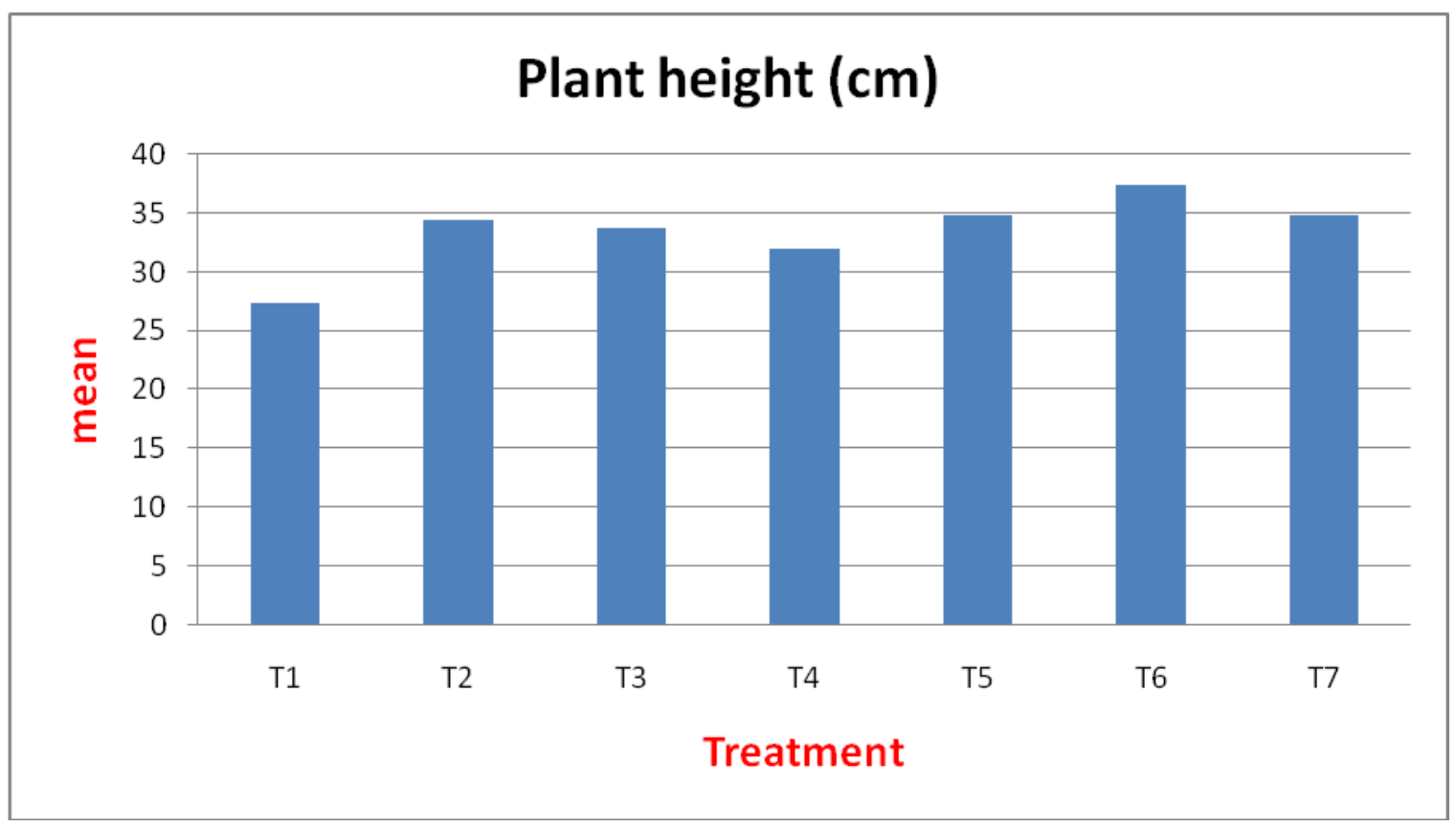


Fig.2 Effect of integrated nutrient management on number of leaves of radish

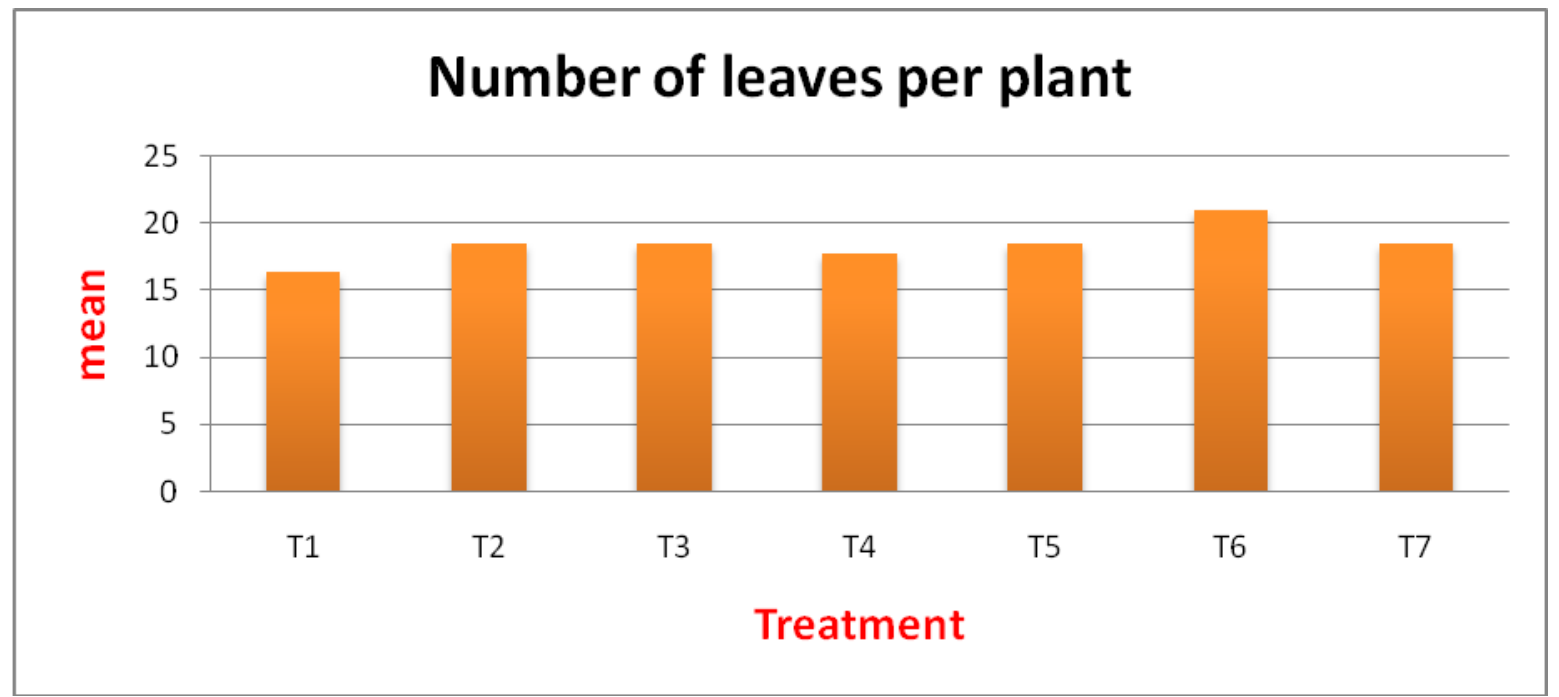

Fig.3 Effect of integrated nutrient management on root length $(\mathrm{cm})$ of radish

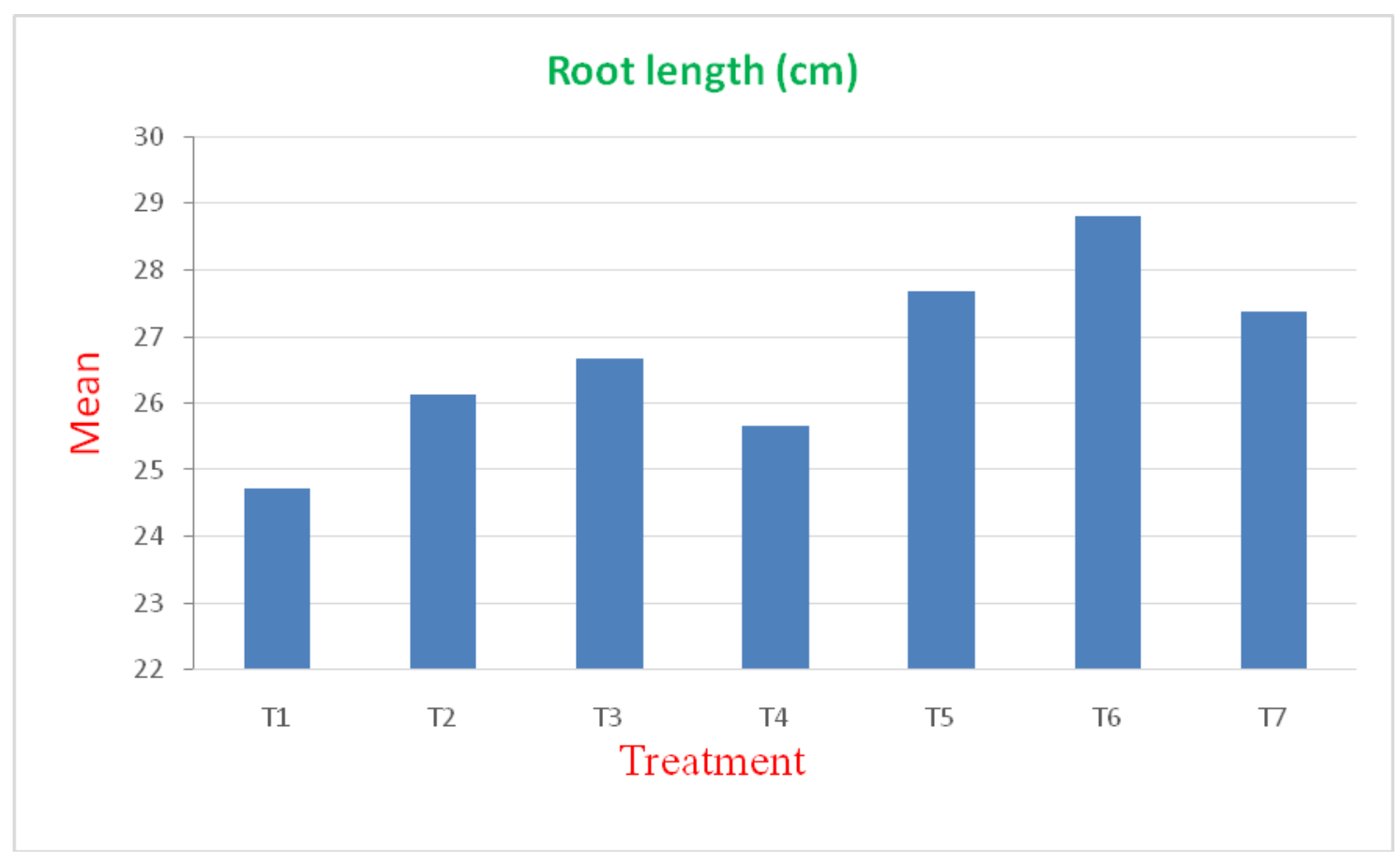


Fig.4 Effect of integrated nutrient management on root diameter $(\mathrm{cm})$ of radish

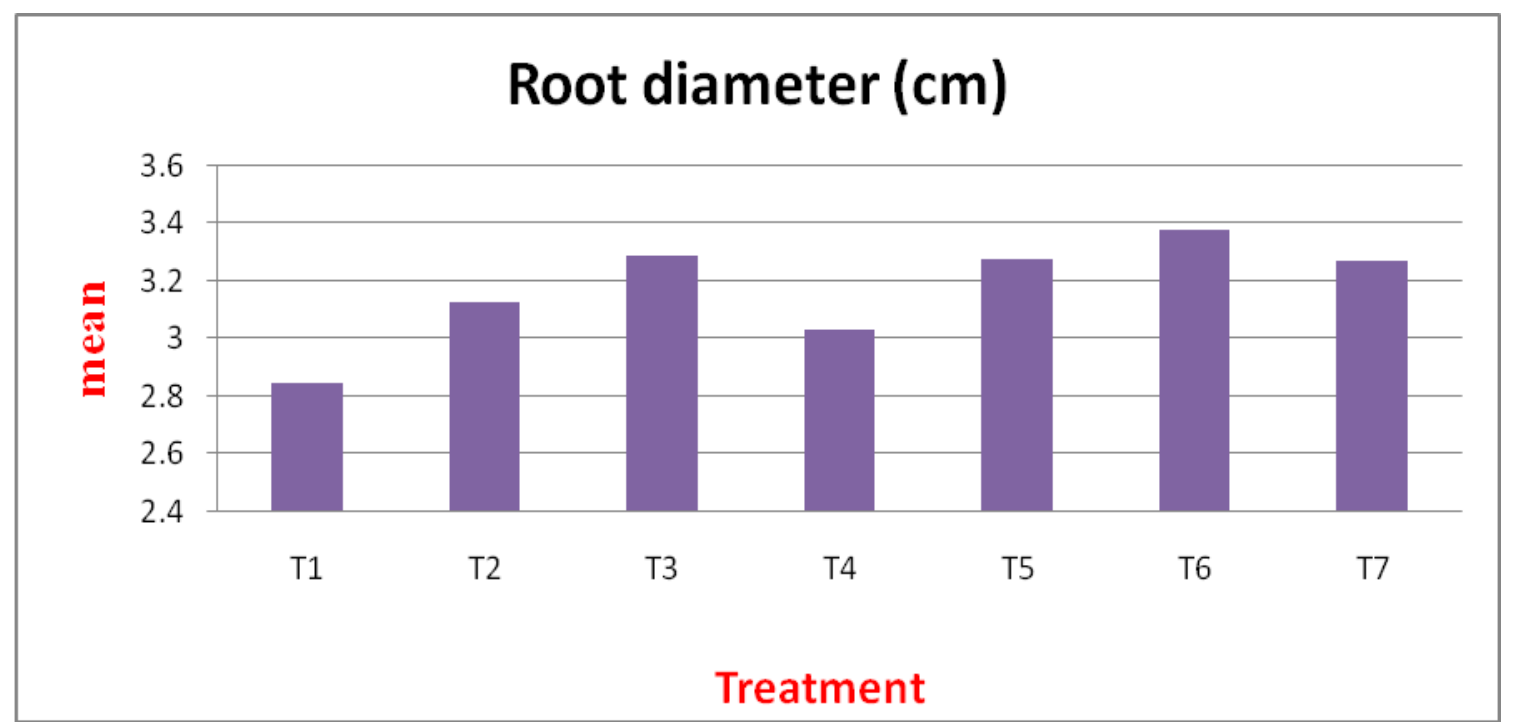

Fig.5 Effect of integrated nutrient management root weight $(\mathrm{g})$ on radish

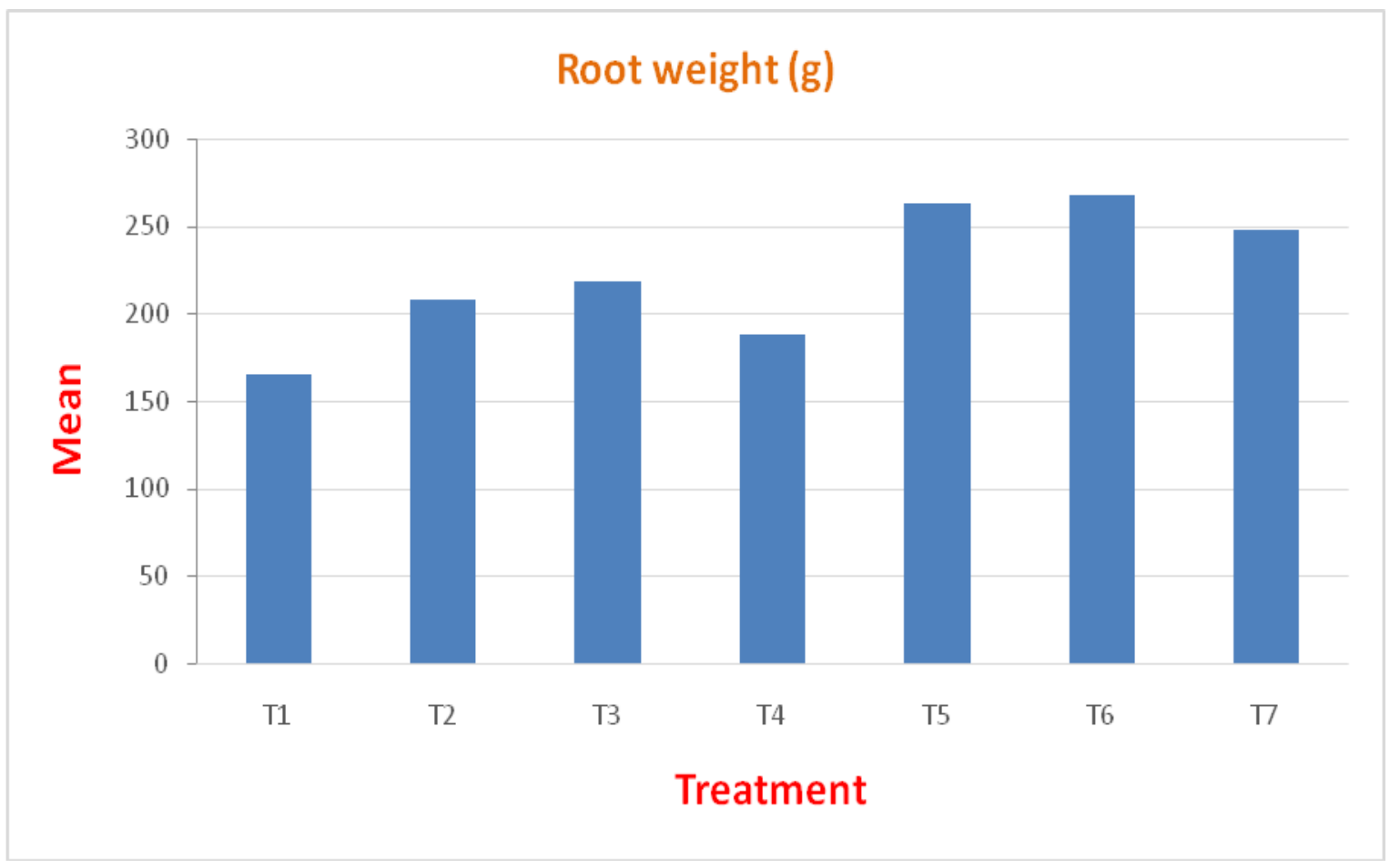

This type of situation reflected in growth and yield parameters directly led to higher yield of radish root yield. Similar result has been reported by Chang and Chang (2000). Ahmed et al., (2004) and Gethe et al., (2006) in radish turnip and onion respectively.

\section{Root weight (g)}

Significantly maximum root weight $\mathrm{T}_{6}$ (267.33g) was recorded with $\mathrm{T}_{6}: \mathrm{T}_{1}+$ vermicompost (5 t/ha) + IIHR microbial consortium (300g). $T_{5}$ and found to be at par 
with $(262.67 \mathrm{~g})$, while significantly minimum root weight $T_{1} \operatorname{RDF}(165 \mathrm{~g})$ was recorded.

Maximum root weight might be due to the nutrients (N.P.K.) supporting for biological synthesis and it also play important role in plant metabolism and being an essential constituent of diverse type metabolically active compounds like purines, pyrimidine's, enzymes, co-enzymes and alkaloids. Thus increased availability of photosynthesis, which consequently led to desirable $\mathrm{C}$ : $\mathrm{N}$ ratio as carbohydrate supplies helping in larger storage in the root as well as shoot.

Which reflected in growth and yield parameters directly for higher yield of radish root yield similar results have been reported by Chang and Chang (2000) Ahmed et al., (2004) and Gethe et al., (2006) in radish turnip and onion respectively.

\section{Root diameter (cm)}

Significantly maximum root diameter of radish $(3.38 \mathrm{~cm})$ was recorded in treatment $\mathrm{T}_{6}$ under the study. It was followed by the treatment $\mathrm{T}_{5}(3.29 \mathrm{~cm})$ and $\mathrm{T}_{7}(3.28 \mathrm{~cm})$ while minimum root diameter $(2.85 \mathrm{~cm})$ was recorded in treatment $T_{1}$.

Maximum root diameter may be due to the increased plant height practices dosage and beneficiary effect of integrated nutrient management.

This might be due to influence of nutrient, the chief constituent of protein which is essential for the formation of protoplasm leading to meristamatic activity, cell division and development of root.

These findings are in agreement with the that of Sunanda and Reddy (2007), Gethe et al., (2006) and Mohammad et al., (2005) in carrot and onion respectively.

\section{References}

Ahmed., F. Sarwar, S. and Khan, B. M. (2004). Effect of different, combinations of NPK fertilizers on the growth and yield of turnip (Brassica rapa L.) at the northern areas of Pakistan. Pakistan-journal-of-soilscience (Pakistan).V.23 (3-4) P.43-4.

Bhuiyan, N. I. A. L., Shaha, and G. M. Panaullah., (1991). Effect of NPK fertilizer on the grain yield of transplanted rice and soil fertility long term study. Bangladesh J. Soil.Sci. 22 (1\&2):41-50.

Chang, L. and Chang, J. (2000). Effect of potassium on yield quality of radish (Raphanus Sativus L.).J. Hebei Agril.University. 23 (2): 20 - 24.

Desuki, M. El., Salman, S. R., El-Nemr, M. A. and Abdel Maywood, M.R. (2005). Effect of plant density and nitrogen application on the growth, yield and quality of radish (Raphanus sativus L.).J. Argon., 4: 225-229.

Gopalan and Balasubramanium, (1966)."Nutritive value of Indian Foods" (6'h revised edn.) ICAR, New Delhi

Gethe, R. M., Pawar, V. S., Pathan, S. H., Sort wane, D. A. and Kadlag, A. D. (2006). Influence of planting layouts, Irrigation Regimes and fertilizer levels on growth and yield of onion under micro-sprinkler. 1. Maharashtra Agric. Univ., 31 (3): 272 - 274.

Lacas, M. D., and De Frietas, F. E., (1960). The response of radishes to nutritional deficiencies of major and minor elements. AgronLustit. 22: 205 - 212.

Mohammad Amjad, Safina Naz, and Sultan Ali. (2005). Growth and seed yield of carrot as influenced by different regimes of nitrogen and potassium. Joural of Research Science 420-425.

Sunanda., N. and Reddy M. K. (2007). Effect 
of different organic manures and Inorganic fertilizers on growth, yield and quality of carrot Daucus carota L.). Karnataka J.Agric. sci., 20(3): 686 -688 .

Velmurugan, M., Balakrishnamoorthy, G. and
Ananthan, M. (2005). Studies on organic farming practices on growth, yield and quality of radish (Raphanus sativus L.) cv. Pusachetki. South Indian Hort., 53 (1-6): 337- 339.

\section{How to cite this article:}

Akshay Sawant, Ch. Raja Goud, T. Suresh Kumar, D. Anitha Kumari and Satish, P. 2021. Study of Integrated Nutrient Management on Growth, Yield and Quality of Radish (Raphanus sativus L.). Int.J.Curr.Microbiol.App.Sci. 10(08): 258-266.

doi: https://doi.org/10.20546/ijcmas.2021.1008.030 